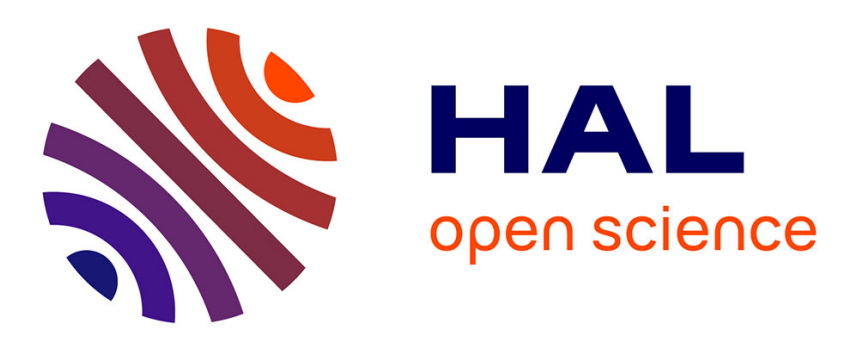

\title{
The effect of ponding depth on infiltration in a crusted surface depression
}

Dennis Fox, Yves Le Bissonnais, Ary Bruand

\section{To cite this version:}

Dennis Fox, Yves Le Bissonnais, Ary Bruand. The effect of ponding depth on infiltration in a crusted surface depression. CATENA, 1998, 32, pp.87 - 100. hal-02572261

\section{HAL Id: hal-02572261 \\ https://hal.science/hal-02572261}

Submitted on 6 Dec 2021

HAL is a multi-disciplinary open access archive for the deposit and dissemination of scientific research documents, whether they are published or not. The documents may come from teaching and research institutions in France or abroad, or from public or private research centers.
L'archive ouverte pluridisciplinaire HAL, est destinée au dépôt et à la diffusion de documents scientifiques de niveau recherche, publiés ou non, émanant des établissements d'enseignement et de recherche français ou étrangers, des laboratoires publics ou privés. 


\title{
The effect of ponding depth on infiltration in a crusted surface depression
}

\author{
D.M. Fox ${ }^{*}$, Y. Le Bissonnais ${ }^{1}$, A. Bruand \\ Institut National de la Recherche Agronomique, Service d'Etude des Sols et de la Carte Pédologique de \\ France, Centre de Recherches d'Orléans, 45160 Ardon, France
}

Received 11 April 1996; accepted 12 January 1998

\begin{abstract}
Over the past few decades, the influence of surface sealing on infiltration has been the subject of numerous publications. However, very few of these experiments have considered the effect of spatial variability in seal hydraulic characteristics on infiltration. Field and laboratory observations have demonstrated that seal characteristics vary considerably within a range of a few $\mathrm{cm}$, and the changes are often related to microtopography. The objective of this experiment was to investigate the influence on infiltration of a seal with varying hydraulic properties in a surface depression. Two soils of different aggregate stability were used in the experiment: Blosseville silt loam and Villamblain silty clay loam. Soil columns $(23 \mathrm{~cm}$ diameter by $30 \mathrm{~cm}$ length) were packed with aggregates of $<2.0 \mathrm{~cm}$ and a $6 \mathrm{~cm}$ depression was formed in the soil surface. A sedimentary crust was formed in the centre of the depression, and the sample was rained upon for $60 \mathrm{~min}$ at a rainfall intensity of $35 \mathrm{~mm} \mathrm{~h}^{-1}$. Subsequently, water outflow at the base of the column and pressure heads in the column were measured during two ponding periods corresponding to depths of 0.5 and $4.0 \mathrm{~cm}$. Water outflow rates increased with ponding depth substantially more than could be attributed to the increases in ponding pressure head and submerged area for both soils. The experiment demonstrated that where seal hydraulic conductivity varies with microtopography, a significant increase in infiltration rate occurs as areas of greater hydraulic conductivity are submerged. The increases in ponded pressure head and submerged area are negligible compared to the influence of spatial variability in seal hydraulic conductivity. (C) 1998 Elsevier Science B.V. All rights reserved.
\end{abstract}

Keywords: Surface depression; Structural crust; Sedimentary crust; Ponding depth; Infiltration

\footnotetext{
${ }^{*}$ Corresponding author. Ecole Supérieure d'Agriculture de Purpan, Département d'Agronomie, 75 voie du T.O.E.C., 31076 Toulouse cedex, France. Fax: +33-2-38-41-78-69; +33-5-61-15-30-60; e-mail: fox@cict.fr

${ }^{1}$ E-mail: lebisson@orleans.inra.fr
} 


\section{Introduction}

Surface crusting has been the subject of numerous studies since the pioneering work of Duley (1939) and McIntyre (1958a,b). These studies have led to the classification of soil crusts into two general categories (Chen et al., 1980; Casenave and Valentin, 1989; Bresson and Boiffin, 1990; West et al., 1992). Aggregate breakdown and coalescence under raindrop impact reduce soil porosity in the upper soil layer to form structural crusts. Sedimentary crusts are formed from the deposition of sediments and micro-aggregates. Sedimentary crusts depend on flow and surface conditions which affect sedimentation; runoff rate, flow velocity, and microtopography strongly influence the spatial distribution of sedimentary crusts. Generally, sedimentary crusts are found in depressions and micro-depressions, and structural crusts are associated with soil mounds. The surface seal significantly reduces infiltration and increases runoff with the potential of accelerating erosion.

Most of the studies dealing with the influence of surface sealing on infiltration rate have used soil columns or trays with a planar soil surface (Sharma et al., 1981; Agassi et al., 1985; Bradford and Ferris, 1987; Chiang et al., 1993). Micromorphological studies have generally worked at a scale of $<1 \mathrm{~mm}$ to $5 \mathrm{~cm}$, a scale which limits the spatial variability that can be observed in a single sample (Epstein and Grant, 1967; Chen et al., 1980; Onofiok and Singer, 1984; Norton, 1987; Luk et al., 1990). In modeling infiltration into surface sealed soils, the seal is generally assumed to be of a uniform thickness for practical reasons. The preferential study of a flat surface and uniform seal has neglected the important spatial variability in seal hydraulic conductivity and thickness found in the field (Freebairn et al., 1991). However, Falayi and Bouma (1975) and Valentin (1991) studied the physical properties and the morphology of crusts formed in the field under natural and tilled conditions. They considered the effect of surface roughness on infiltration and observed a better infiltration in the remaining clods than in the sedimentary crusts. Sedimentary crusts tend to be thicker than structural crusts, so even in the absence of significant differences in hydraulic conductivity, infiltration rates into structural crusts would be expected to be greater. The influence of this spatial variability on infiltration has yet to be examined experimentally.

Aboujaoudé et al. (1991) attempted to model infiltration into a crusted soil with a sinusoidal surface configuration and varying thickness. Their objective was to compare two approaches (two-layer and impedance) to infiltration modeling in crusted soils, and they did not examine the effect of varying the ponding depth in the depression nor did they present experimental results. The two approaches gave similar results, but the impedance model was simpler to use. In a model developed by Bristow et al. (1995), surface seals were associated with depressions and mounds remained uncrusted. The model predicted significantly different infiltration rates if the ponded water in the depressions were allowed to run off or not. The modeling attempt was not accompanied by experimental observations, but it suggests that spatially varying crust characteristics in a depression can influence infiltration rate.

Including spatially varying crust characteristics in models substantially increases model complexity and computation time. The influence of this variability on infiltration rate must be quantified in order to justify the added cost and effort. This study is a first 
step in this direction. In this initial stage, a simple depression with varying crust characteristics and ponding depth was replicated in a soil column. Surface sealing was most intense in the centre of the depression and least developed on the depression walls. The situation was rendered more complex in a second stage where crust characteristics varied naturally with a mound and depression microtopography (Fox et al., 1998).

The objective of this study was to investigate the influence of ponding depth on infiltration rate in a depression capped with a seal of varying thickness and porosity. Two ponding depths were selected: $0.5 \mathrm{~cm}$ (shallow) and $4.0 \mathrm{~cm}$ (deep), and two soils of distinctly different aggregate stability were tested.

\section{Methods}

Properties of the two soils used are listed in Table 1. Blosseville is a silt loam from Pays de Caux, and Villamblain is a silty clay loam from Petite Beauce (France). Both soils were collected from the upper $10-15 \mathrm{~cm}$, dried to a gravimetric moisture content of about $10 \%$ and stored in sealed containers at a temperature of $5^{\circ} \mathrm{C}$. Sufficient material to fill a $30 \mathrm{~cm}$ long column with a diameter of $23.5 \mathrm{~cm}$ was sieved to retain the $<2.0 \mathrm{~cm}$ aggregates and packed in the column to an average uniform bulk density of about $1.3 \mathrm{~g}$ $\mathrm{cm}^{-3}$. The surface was molded to form a depression of the general form shown in Fig. 1 .

Rainfall simulations $\left(35 \mathrm{~mm} \mathrm{~h}^{-1}\right.$ ) were performed using a drop-type simulator with a fall height of $2 \mathrm{~m}$. Rainfall characteristics are given in Le Bissonnais et al. (1995). In order to replicate the formation of a sedimentary crust in the depression, $80 \mathrm{~cm}^{3}$ of fine sediments (diameter $<0.2 \mathrm{~cm}$ ) were added to the surface shortly after the initiation of rainfall. This pattern of a sedimentary crust forming rapidly over top of a structural crust was similar to the experimental observations of Freebairn et al. (1991). Sedimentary seals are frequently composed of successive laminae of sorted sediments (Bresson and Boiffin, 1990) but can be composed of material of varying size detached from neighbouring mounds (Bradford and Huang, 1991). The physical behaviour of the sedimentary seals here with regards to infiltration was consistent with that of sedimentary seals of the same soil formed under rainfall (Fox et al., 1998). Although the method of adding sediments was of no interest for a study of crust formation, it replicated the physical behaviour of the seals sufficiently for the objectives of the experiment. The crust configuration for the depression resembled the situation in Fig. 1. The maximum thickness of the sedimentary crust was about $1.0-1.5 \mathrm{~cm}$ and it thinned outwards to a

Table 1

Selected physical and chemical soil properties of Blosseville and Villamblain

\begin{tabular}{llllllll}
\hline Soil type & $\begin{array}{l}\text { Clay } \\
0-2 \mu \mathrm{m}\end{array}$ & $\begin{array}{l}\text { Fine silt } \\
\left(\mathrm{g} \mathrm{kg}^{-1}\right)\end{array}$ & $\begin{array}{l}\text { Coarse silt } \\
\left(\mathrm{g} \mathrm{kg}^{-1}\right)\end{array}$ & $\begin{array}{l}\text { Fine sand } \\
\left(\mathrm{g} \mathrm{kg}^{-1}\right)\end{array}$ & $\begin{array}{l}\text { Coarse sand } \\
\left(\mathrm{g} \mathrm{kg}^{-1}\right)\end{array}$ & $\begin{array}{l}\text { Organic carbon } \\
\left(\mathrm{g} \mathrm{kg}^{-1}\right)\end{array}$ & $\begin{array}{l}\text { CEC } \\
\left(\mathrm{cmol} \mathrm{kg}^{-1}\right)\end{array}$ \\
\hline Blosseville & 130 & 152 & 425 & 280 & 13 & 10.8 & 10.5 \\
Villamblain & 335 & 297 & 328 & 20 & 20 & 13.1 & 19.6 \\
\hline
\end{tabular}




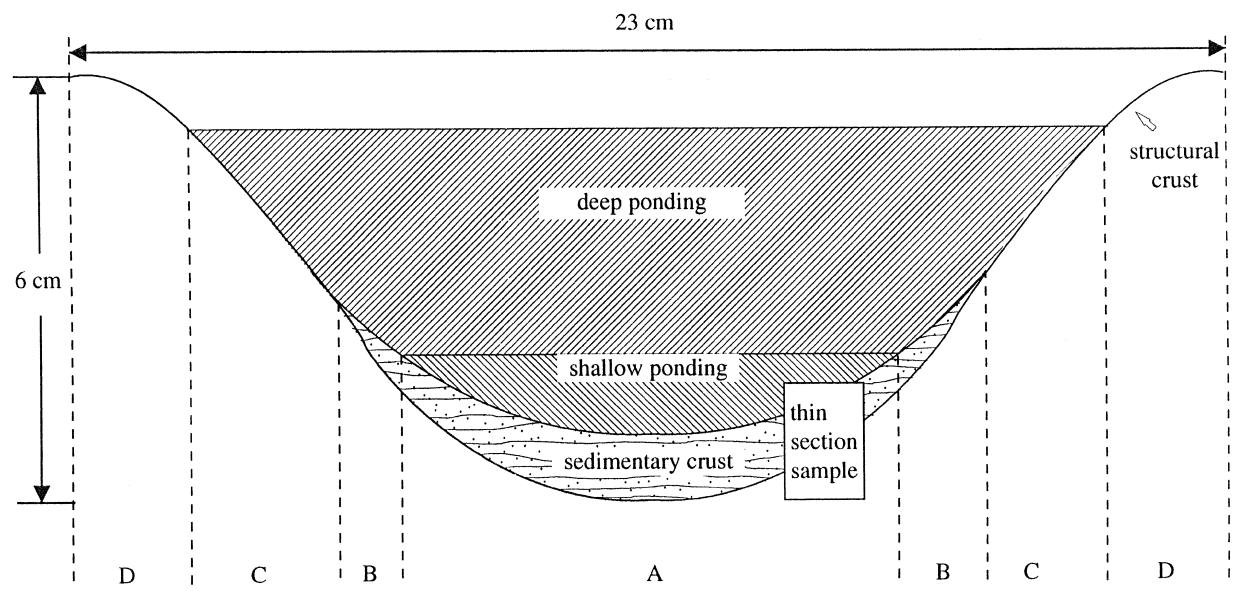

Fig. 1. Schematic representation of soil surface depression showing the approximate configuration of the sedimentary and structural crusts and the location of the thin section samples.

boundary at a distance of about $6 \mathrm{~cm}$ from the center of the depression. Specific characteristics of the crusts will be described in more detail with the aid of thin sections in the Results. Rainfall simulations lasted 1 hour. Six replicates of each soil type were included in the experiment.

After the rainfall simulation, the depth of ponding in the depression was noted. The sample was then set on a stand, as shown in Fig. 2, and ponded to a depth of $0.5 \mathrm{~cm}$ overnight. This ponding period was necessary for the wetting front to reach the base of the column. The setup shown in Fig. 2 included a rainfall intensity identical to that of the initial simulation with the option of an added input of water to the depression.

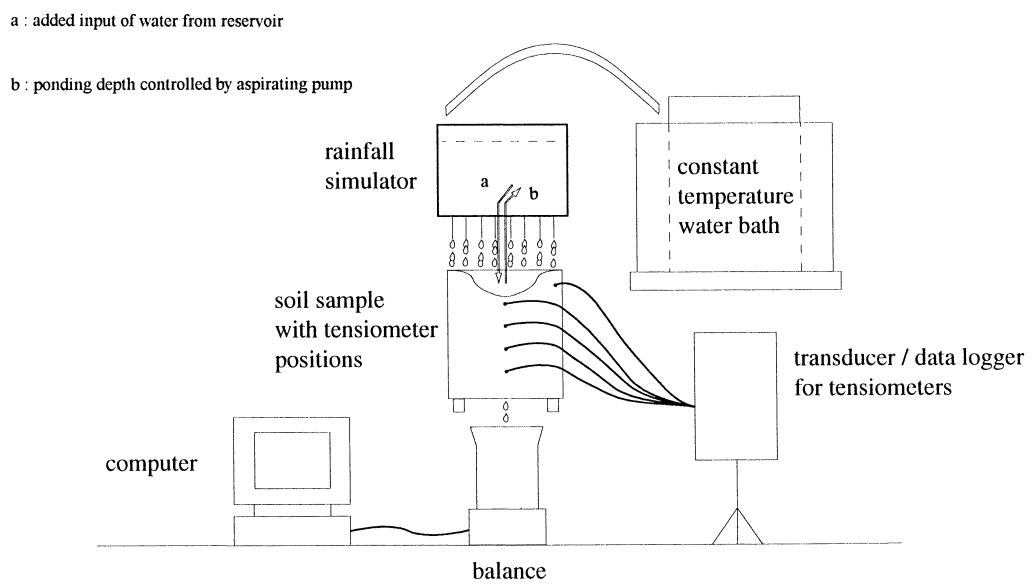

Fig. 2. Experimental setup: water at constant temperature was supplied to the rainfall simulator and directly into the depression under deep ponding. Ponding depth was controlled by an aspirator pump, and the water flux was measured continuously. 
Distilled, temperature controlled $\left(19^{\circ} \mathrm{C}\right)$ water was used. Ponding depth at the surface was controlled with an aspirating pump. The soil surface was protected with a highly permeable cloth to prevent seal disruption from the aspirating pump or raindrop impact.

After ponding overnight, water outflow through the base of the column was collected in a beaker on a balance linked to a computer which automatically recorded the cumulative outflow every $3 \mathrm{~min}$. Microtensiometers $(0.6 \mathrm{~cm}$ outer diameter, $0.3 \mathrm{~cm}$ inner diameter, $2.5 \mathrm{~cm}$ length, 1.5 bars air entry value) were inserted at depths of 7.5, 12, 18, and $24 \mathrm{~cm}$ as shown in Fig. 2. These were connected to an automated transducer-recorder system and pressure head values in the column were recorded every $12 \mathrm{~min}$.

For the shallow depth, rainfall alone was used to supply sufficient water input to maintain the $0.5 \mathrm{~cm}$ depth. Cumulative water outflow rate and pressure head were recorded during about $3 \mathrm{~h}$ before increasing the depth to $4.0 \mathrm{~cm}$. For this depth, both rainfall and direct input of water were used. Cumulative water outflow rate and pressure head were also recorded for this depth during a period of about $3 \mathrm{~h}$.

After each simulation, the surface topography was measured using a rod and ruler system ( $1 \mathrm{~cm}$ spacing). The position of the sedimentary crust boundary was also noted. The cross-section of the topography was used to calculate the ponding depths and areas for each treatment and sample as shown in Fig. 1. GIS software, ArcInfo (ESRI, 1992), was used to measure the perimeter of the surface under ponding for individual cross-sections for each sample, and this was used to calculate mean ponding depth and ponded surface area for each crust section and treatment.

Surface samples were taken for thin sections as shown in Fig. 1. They were oven-dried at $40^{\circ} \mathrm{C}$ before impregnation with a polyester resin (Bruand et al., 1996). The thin sections were studied using optical microscopy, at both low and high magnification, and scanning electron microscopy in the backscattered electron mode (Bisdom and Thiel, 1981; Le Bissonnais and Bruand, 1993).

\section{Results}

\subsection{Thin sections}

Fig. 3 shows backscattered electron scanning images (BESI) of the samples collected from the soil surface for Blosseville and Villamblain. The objective of the thin section analysis was to describe differences in porosity and define the crust thicknesses needed to solve for seal hydraulic conductivity as will be discussed shortly. No attempt was made to characterize the crusts beyond the broad classifications of sedimentary and structural as was performed by Boiffin (1985) and Bresson and Boiffin (1990) and as would normally have been done with field samples.

For Blosseville, the layer of fine sediments which was added was not easily distinguishable because of the collapse of the soil structure within the entire column. The thickness of this layer ranged from about 0.4 to $1.1 \mathrm{~cm}$ (Fig. 3a). From the surface down to a depth of about $0.2-0.3 \mathrm{~cm}$, a few of the initial aggregates could be seen embedded within the closely packed silt particles. Voids ranged from about 5 to $20 \mu \mathrm{m}$ 
Blosseville silt loam

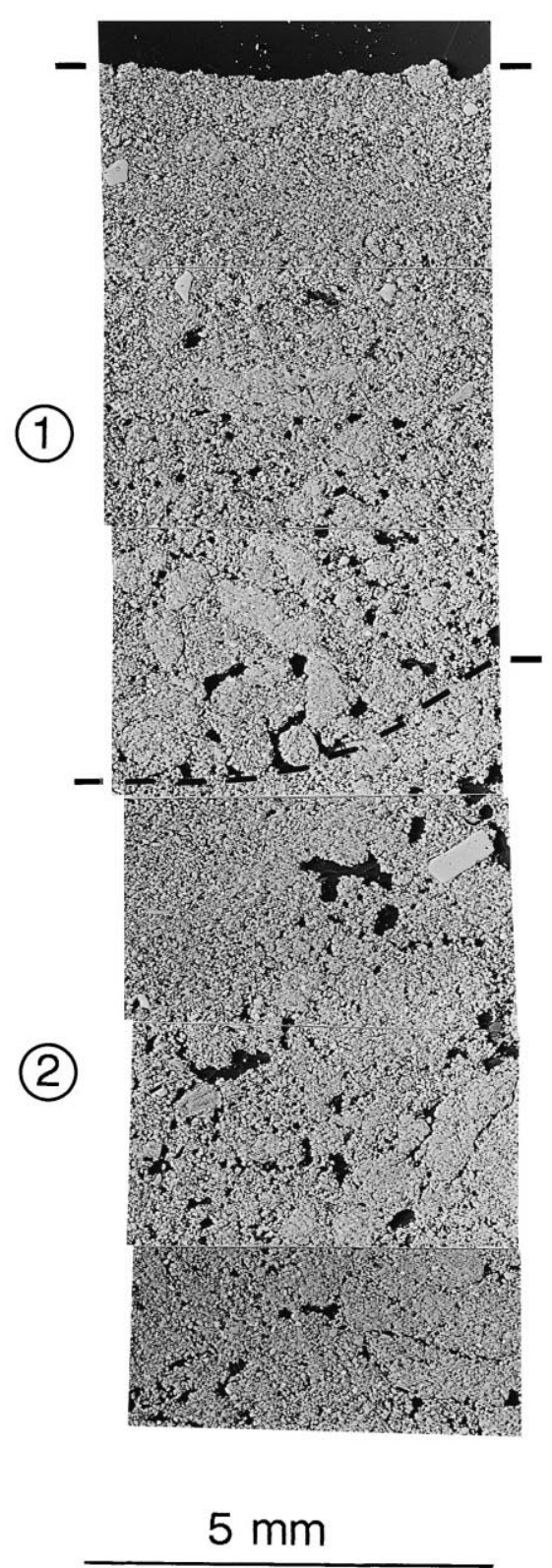

Villamblain silty clay loam

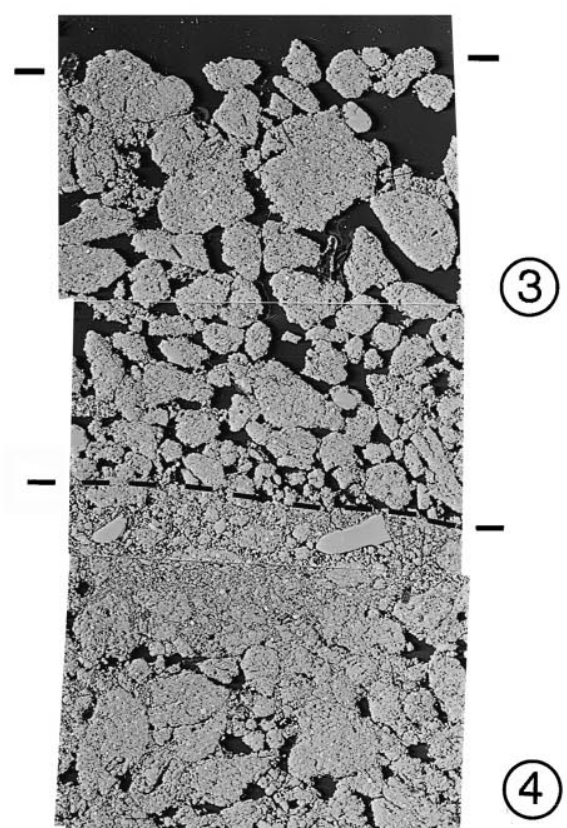

(4) 
in size. Below, this sedimentary layer, numerous initial aggregates of about 0.05 to 0.15 $\mathrm{cm}$ in size could be seen, with silt particles filling the aggregate packing voids. Voids in this zone ranged from about 5 to $200 \mu \mathrm{m}$ in size. On the depression side, the material showed a collapsed structure with voids ranging from about 5 to $500 \mu \mathrm{m}$ in size.

For Villamblain, the layer of sediments added to the surface was easily delimited because the initial structure remained relatively intact throughout the experiment. Its thickness ranged from about 0.4 to $1.4 \mathrm{~cm}$. Overlying the added fine sediments, loosely packed aggregates of about 0.1 to $0.2 \mathrm{~cm}$ in size without fine material filling the packing voids could be observed (Fig. 3b). The first 0.1 to $0.2 \mathrm{~cm}$ beneath this layer showed a close fabric where aggregates from the added sediments were still visible. They were embedded in fine material constituted of elementary particles of the sediment. The voids were about 2 to $10 \mu \mathrm{m}$ in size. Underneath, the soil exhibited a loose packing of initial aggregates $<0.2 \mathrm{~cm}$ in size where material and the packing voids were about 200 to $800 \mu \mathrm{m}$ in size. On the slope of the depression, the surface was composed of an irregular layer of about 0.05 to $0.5 \mathrm{~cm}$ in thickness; this structural seal was constituted of aggregates of about 0.02 to $0.1 \mathrm{~cm}$ in size, and the voids were about 50 to $500 \mu \mathrm{m}$ in size.

\subsection{Infiltration}

Infiltration was not measured directly since it is defined as the flux density of water entering a soil at its surface. Percolation through the base of the column was measured, and it was assumed that at steady state the percolation flux was the same as the infiltration flux. The volumetric percolation rate was converted to an infiltration flux density $\left(\mathrm{mm} \mathrm{h}^{1}\right)$ by dividing by the surface area of the soil sample.

Fig. 4 shows representative curves of cumulative percolation water outflow for Blosseville and Villamblain. Ponding depth was changed from $0.5 \mathrm{~cm}$ to $4.0 \mathrm{~cm}$ at about $215 \mathrm{~min}$ for Blosseville and $260 \mathrm{~min}$ for Villamblain. With the increase in ponding, the slope of the cumulative water outflow curve increased for both soils. Linear regression was performed on each ponding segment of the cumulative outflow curves for each replicate to obtain steady state percolation rates $\left(r^{2}\right.$ values were consistently $\left.>0.99\right)$.

Steady state percolation rates were converted to final infiltration rates $\left(\mathrm{mm} \mathrm{h}^{-1}\right)$ as described above and are plotted in Fig. 5. In the remainder of the paper, the term 'final infiltration rate' will be shortened to 'infiltration rate'. Villamblain had higher infiltration rates under both ponding treatments. This reflects differences in aggregate stability between the two soils and their relative susceptibility to surface sealing: Blosseville has a very low aggregate stability and forms a surface seal much more readily than does Villamblain (Le Bissonnais and Bruand, 1993; Le Bissonnais et al., 1995). Infiltration

\footnotetext{
Fig. 3. Backscattered Electron Scattering Images (BESI) of crust sections (sample locations shown in Fig. 1). 1 - Sedimentary crust with, at the base, close packing of remaining initial aggregates with disaggregated material. 2-Collapsed structure of initial soil with few remaining aggregates. 3-Depression infilling with detached aggregates. 4-Sedimentary crust with at the bottom a loose packing of initial aggregates. 5-Initial soil structure with numerous initial aggregates in loose packing.
} 


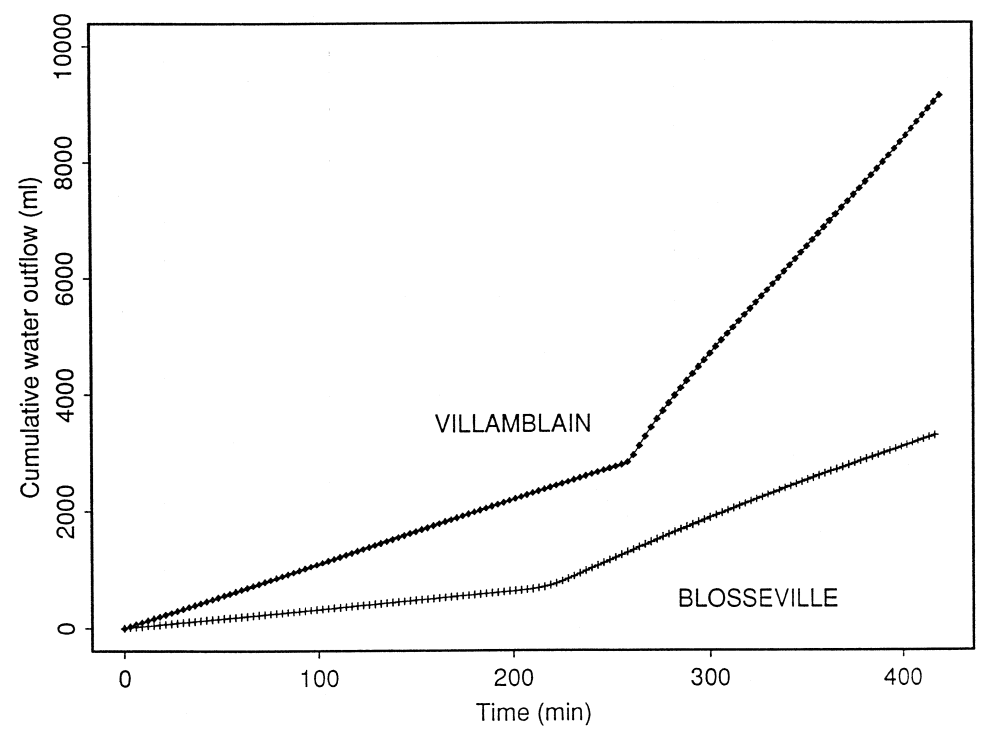

Fig. 4. Cumulative water outflow for selected samples. Ponding depth was changed at about 215 min for Blosseville and at about 260 min for Villamblain.

rate increased with ponding depth for both soils, but the increase was much greater for Villamblain. For this soil, a ponding depth of $4.0 \mathrm{~cm}$ could be maintained only with the added input of water since the infiltration rate was almost twice the rate of the rainfall

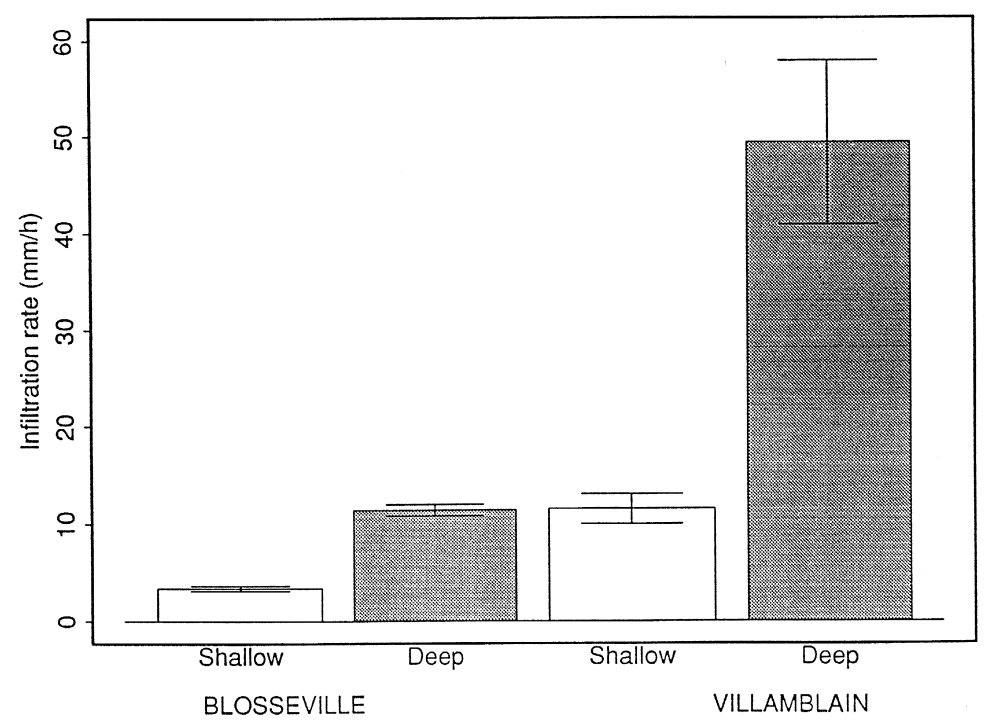

Fig. 5. Mean infiltration rates for Blosseville and Villamblain under shallow $(0.5 \mathrm{~cm})$ and deep $(4.0 \mathrm{~cm})$ ponding (error bars are \pm 1 standard error). 


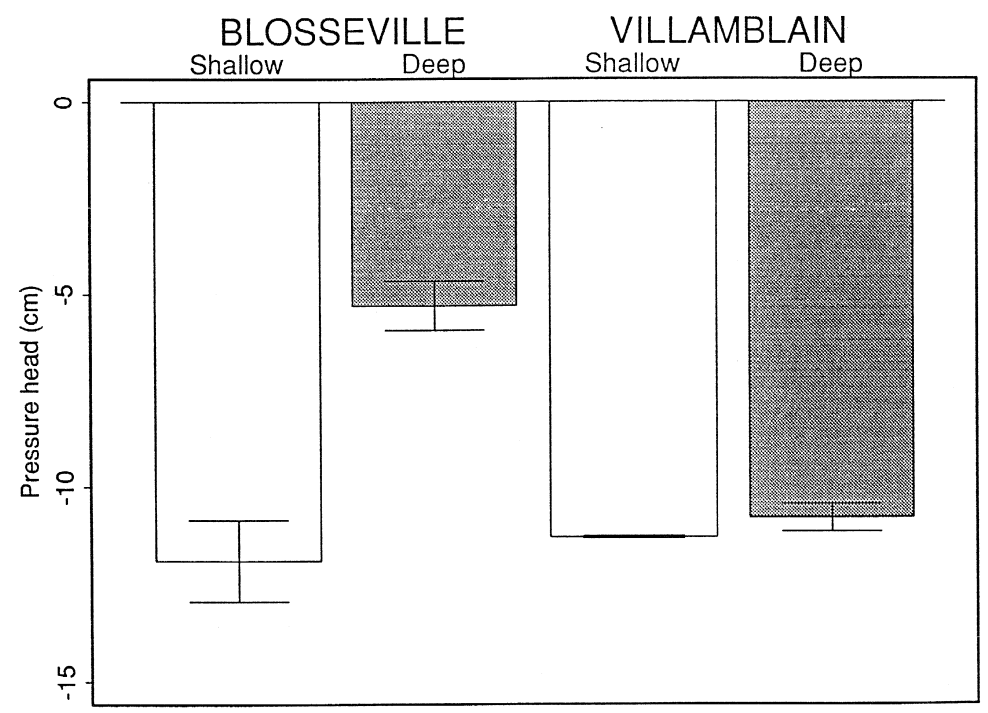

Fig. 6. Mean pressure heads for Blosseville and Villamblain under shallow $(0.5 \mathrm{~cm})$ and deep $(4.0 \mathrm{~cm})$ ponding (error bars are \pm 1 standard error).

intensity. An analysis of variance test $\left(r^{2}=0.92\right)$ showed that infiltration rate was significantly affected by both soil type $(\alpha=0.001)$ and ponding depth $(\alpha=0.001)$.

\subsection{Subseal pressure head}

The range in pressure head values within the column was greater for Blosseville, but both soils showed an increase in pressure head with increasing ponding depth. Mean pressure heads of all replicates are plotted in Fig. 6. The increase in pressure head is greater for Blosseville than for Villamblain, despite the substantially greater increase in infiltration rate for Villamblain. This difference is probably related to the difference in clay content between the two soils which implies that they have different moisture characteristic curves. An analysis of variance test $\left(r^{2}=0.88\right)$ confirmed that the increase in pressure head with ponding depth was statistically significant for both soils ( $\alpha=0.001)$. Pressure head values also differed according to soil type $(\alpha=0.01)$, reflecting the different textural and aggregation properties of the two soils.

\section{Discussion}

Although the experiment was a highly idealized and simplified simulation of a puddled depression, the response of the two soils was consistent with field observations. For Villamblain, ponding depth during the initial hour of rainfall increased until the infiltration rate equalled the input rate (mean post-rainfall depth $=1.6 \mathrm{~cm}$ ). In the field, puddling is frequently observed in depressions and wheel tracks but runoff rarely occurs. 
In contrast, ponding depth for Blosseville continued to rise steadily and would have overflowed eventually if sufficient time had been allowed (mean post-rainfall depth $=3.3$ $\mathrm{cm})$. The depth of the column depression was greater than what is usually found in the field, and this soil generates runoff for rainfall of even very low intensity (4-6 mm $\left.\mathrm{h}^{-1}\right)$.

$$
\begin{aligned}
q= & a K\left(\frac{h o-h+z}{z}\right) \\
q_{\mathrm{sh}}= & {\left[a_{\mathrm{A}} k_{\mathrm{sh}}\left(\frac{h_{\mathrm{o}}-h_{\mathrm{sh}}+z_{\mathrm{s}}}{z_{\mathrm{s}}}\right)_{\mathrm{A}}\right]+\left[a_{\mathrm{B}} k_{\mathrm{sh}}\left(\frac{h_{\mathrm{o}}-h_{\mathrm{sh}}+z_{\mathrm{s}}}{z_{\mathrm{s}}}\right)_{\mathrm{B}}\right] } \\
& +\left[a_{\mathrm{CD}} k_{\mathrm{sh}}\left(\frac{h_{\mathrm{o}}-h_{\mathrm{sh}}+z_{\mathrm{c}}}{z_{\mathrm{c}}}\right)_{\mathrm{CD}}\right] \\
q_{\mathrm{d}}= & {\left[a_{\mathrm{AB}} k_{\mathrm{d}}\left(\frac{h_{\mathrm{o}}-h_{\mathrm{d}}+z_{\mathrm{s}}}{z_{\mathrm{s}}}\right)_{\mathrm{AB}}\right]+\left[a_{\mathrm{C}} k_{\mathrm{d}}\left(\frac{h_{\mathrm{o}}-h_{\mathrm{d}}+z_{\mathrm{c}}}{z_{\mathrm{c}}}\right)\right.} \\
& +\left[a_{\mathrm{D}} k_{\mathrm{d}}\left(\frac{h_{\mathrm{o}}-h_{\mathrm{d}}+z_{\mathrm{c}}}{z_{\mathrm{c}}}\right)_{\mathrm{D}}\right]
\end{aligned}
$$

$q=$ flux $\left(\mathrm{cm}^{3} \mathrm{~h}^{-1}\right) ; s=$ sedimentary crust; $a=$ area $\left(\mathrm{cm}^{2}\right) ; c=$ structural crust; $h_{\mathrm{o}}=$ ponded pressure head $(\mathrm{cm}) ; d=$ deep ponding; $h=$ subseal pressure head $(\mathrm{cm}) ; \mathrm{sh}=$ shallow ponding; $z=$ seal thickness $(\mathrm{cm}) ; \mathrm{A}, \mathrm{B}, \mathrm{C}, \mathrm{D}=$ sections shown in Fig. 1; $K=$ hydraulic conductivity $\left(\mathrm{cm} \mathrm{h}^{-1}\right)$.

Flow into a crust-capped soil can be described using the Darcy equation as shown in Eq. (1) (Hillel and Gardner, 1969). In this experiment, soil surface area under ponding and ponding pressure head both increased with the increase in ponding depth. Theoretically, the increase in infiltration rate observed could have been due to the combined increases in ponded area and ponding pressure head alone. These changes must therefore be taken into account if the influence of spatial variability is to be examined. Eqs. (2) and (3) describe the flux for the shallow and deep ponding conditions, respectively. For each ponding depth, ponded surface area and mean ponding depth are adjusted for each crust section shown in Fig. 1. Data for these adjustments were obtained from the topographic cross-sections and ArcInfo measurements.

The mean crust thicknesses of the sedimentary and structural seals were obtained from the thin sections and included in the calculations. Similarly, mean subseal pressure heads were varied for each ponding condition using measured values. Mean hydraulic conductivity of the sample surface layer can be estimated by solving for $k_{\text {sh }}$ in Eq. (2) for shallow ponding and for $k_{\mathrm{d}}$ in Eq. (3) for deep ponding. However, hydraulic conductivities of the sedimentary and structural seals cannot be calculated individually: pressure head measurements are means for fluxes under both crusts, so they are distinctive of neither. In addition, if the water content of the structural crust increased under deep ponding, then its hydraulic conductivity would have increased also, and it could not be considered a constant in Eqs. (2) and (3). An increase in water content in the structural seal would be expected if its hydraulic conductivity were close to or greater than the rainfall input rate of $35 \mathrm{~mm} \mathrm{~h}^{-1}$. Since the infiltration rate for 
Villamblain is greater than this value under deep ponding, it is probable that water content, and consequently hydraulic conductivity, increased for portions of the structural crust under deep ponding.

The equations can be used to estimate what will be called an 'effective hydraulic conductivity' for each ponding depth. The effective hydraulic conductivity is the mean hydraulic conductivity of the entire surface. If the increase in water outflow were due mainly to the changes in ponding pressure head and ponded area, or to the variability in seal thickness, then the effective hydraulic conductivity would be approximately constant under both shallow and deep ponding.

The mean effective hydraulic conductivities calculated from the six replicates for each soil type are plotted in Fig. 7. As expected, effective hydraulic conductivities are much lower for Blosseville than for Villamblain. With the increase in ponding depth, both soils increase in effective hydraulic conductivity, though the increase is minor for Blosseville. In an analysis of variance test $\left(r^{2}=0.94\right)$, effective hydraulic conductivity was statistically related to soil type $(\alpha=0.001)$ and ponding depth $(\alpha=0.001)$. The proportion of the increase in infiltration rate that can be attributed to the changes in ponding pressure head and ponded area can be estimated by holding the other parameters constant and varying only ponded area and ponding pressure head. The estimated increase in infiltration rate with increasing ponding depth is about $0.1 \mathrm{~mm} \mathrm{~h}^{-1}$ for Blosseville and about $2.5 \mathrm{~mm} \mathrm{~h}^{-1}$ for Villamblain. This estimated increase is in the order of that predicted by Philip (1958), which is about $2 \%$ for each cm increase in ponding depth. The actual increases were $8 \mathrm{~mm} \mathrm{~h}^{-1}$ and $38 \mathrm{~mm} \mathrm{~h}^{-1}$ for Blosseville and Villamblain, respectively. The dominant factor influencing the increase in infiltration rate appears to be the difference in seal hydraulic conductivity between the sedimentary

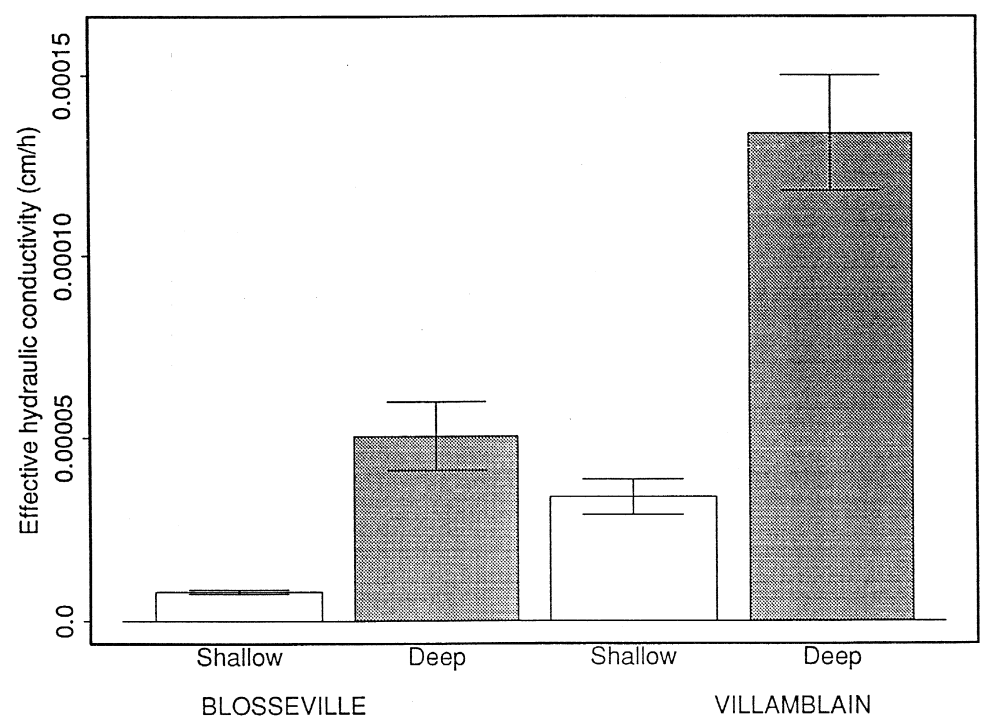

Fig. 7. Mean effective hydraulic conductivities for Blosseville and Villamblain under shallow $(0.5 \mathrm{~cm})$ and deep $(4.0 \mathrm{~cm})$ ponding (error bars are \pm 1 standard error). 
and structural seals, as can be inferred from the changes in effective hydraulic conductivity and thin section analysis.

Infiltration rate was more closely correlated to inundated surface area for Villamblain than for Blosseville (Pearson $r=0.92$ for Villamblain and 0.56 for Blosseville). Infiltration rate was therefore more closely related to the area of structural crust inundated for Villamblain than for Blosseville. This can be explained by the much greater hydraulic conductivity of the Villamblain structural crust. The hydraulic conductivity of the structural seal was greater than that of the sedimentary seal for Blosseville, but the difference appears smaller than for Villamblain. Therefore, the increase in infiltration rate with increased ponding depth for Blosseville was smaller.

In a similar study by Freebairn et al. (1991), the authors found that ponding depth in a ridge-furrow surface configuration simulated in laboratory had a negative effect on final infiltration rate. The negative influence was attributed to the formation of a thicker sedimentary crust under deep ponding. In this experiment, crust characteristics were maintained constant, so the influence of ponding depth was the only changing variable, and the results are consistent with the trend predicted by the model simulations of Bristow et al. (1995). The results of Freebairn et al. (1991) indicate that similar studies which permit a dynamic interaction between ponding depth and crust characteristics should be undertaken. Such an approach was used by Fox et al. (1998) who varied runoff rate in a mound and depression microtopography, and the results were entirely consistent with the observations reported here, as were the results of Falayi and Bouma (1975) and Valentin (1991): structural crusts had higher hydraulic conductivities than sedimentary crusts.

Surface crusts formed under rainfall undergo shrinkage and hardening upon drying (Valentin, 1986) which may further reduce porosity. Crusts undergo several sequences of rainfall impact and deposition under rainfall followed by drying and hardening. It is likely that these processes would accentuate the differences in hydraulic conductivity between structural and thicker sedimentary seals. Structural and sedimentary seals represent two stages in the crusting process (Boiffin, 1985). Structural seals form initially under raindrop impact and sedimentary seals form subsequently at the onset of runoff and ponding. Hydraulic characteristics of the two crusts would be expected to evolve over time, though probably not at the same rate. Structural crusts may reach an equilibrium between sediment detachment and crust compaction relatively quickly depending on initial aggregate size (Farres, 1978). Sedimentary crusts, however, result from a cumulative process of sediment deposition over successive rainfall events. Hydraulic properties of these crusts will evolve as a function of surface roughness (depth and distribution of depressions). In this case, it is also likely that differences in hydraulic conductivity between the two crust types would increase with time until equilibrium hydraulic conductivities are reached.

\section{Conclusions}

The situation replicated in the experiment was that of a depression where the hydraulic characteristics of the surface seal varied with microtopography. In such a case, 
an increase in ponding depth inundates areas of higher hydraulic conductivity and infiltration rate increases significantly. The increase is proportional to the difference in hydraulic conductivity between the sedimentary seal in the depression and the structural seal on its side. This variability appears related to soil aggregate stability. Soils with weak aggregate stability tend to form seals of low hydraulic conductivity everywhere, so even though structural seals are thinner and more porous than sedimentary seals, they are still of sufficiently low hydraulic conductivity to restrict infiltration. Changes in ponding depth in the order of a few $\mathrm{cm}$ as induced in this experiment probably occur in the field only in areas of flow convergence, such as in the concavity of footslopes, for example. The conditions of the experiment were extremely simplified, but the results suggest that spatial variability in seal characteristics can strongly influence the response of infiltration under conditions of varying ponding depth. The range in crust hydraulic conductivity variability found in the field should be quantified in order to determine its importance for runoff generation and erosion processes.

\section{References}

Aboujaoudé, A., Belleudy, Ph., Vauclin, M., 1991. A numerical study of infiltration through crusted soils: flat and other surface configurations. Soil Technol. 4, 1-18.

Agassi, M., Morin, J., Shainberg, I., 1985. Effect of raindrop impact energy and water salinity on infiltration rates of sodic soils. Soil Sci. Soc. Am. J. 49, 186-190.

Bisdom, E.B.A., Thiel, F., 1981. Backscattered electron scanning images of porosities in thin sections of soils, weathered rocks and oil gas reservoirs using SEM-EDXRA. In: Bisdom, E.B.A. (Ed.), Submicroscopy of Soils and Weathered Rocks. Centre of Agricultural Publishing and Documentation (Pudoc), Wageningen, The Netherlands, pp. 191-206.

Boiffin, J., 1985. Stages and time-dependency of soil crusting in situ. In: Callebaut, F., Gabriels, D., De Boodt, M. (Eds.), Assessment of Soil Surface Sealing and Crusting. Proc. of international symposium, Ghent, Belgium, pp. 91-98.

Bradford, J.M., Ferris, J., 1987. Effect of surface sealing on infiltration, runoff, and rainsplash erosion. In: Fok, Y.S. (Ed.), Pre-conference proceedings of the international conference on Infiltration: development and applications, University of Hawaii at Manoa. U.S. Department of Agriculture, pp. 417-428.

Bradford, J.M., Huang, C., 1991. Mechanisms of crust formation: physical components. In: Sumner, M.E., Stewart, B.A. (Eds.), Soil Crusting, Chemical and Physical Processes. Advances in Soil Science. Lewis Publishers U.S.A., pp. 1-17.

Bresson, L.M., Boiffin, J., 1990. Morphological characterization of soil crust development stages on an experimental field. Geoderma 47, 301-325.

Bristow, K.L., Cass, A., Smetten, K.R.J., Ross, P.J., 1995. Water entry into sealing, crusting and hardsetting soils, a review and illustrative simulation study. In: So, H.B., Smith, G.D., Raine, S.R., Schafer, B.M., Loch, R.J. (Eds.), Sealing, Crusting and Hardsetting Soils: Productivity and Conservation. Australian Society of Soil Science, Queensland Branch, pp. 183-204.

Bruand, A., Cousin, I., Nicoullaud, B., Duval, O., Bégon, J.C., 1996. Backscattered electron scanning images of soil porosity for analyzing soil compaction around roots. Soil Sci. Soc. Am. J. 60, 895-901.

Casenave, A., Valentin, C., 1989. Les états de surface de la zone sahélienne. Influence sur l'infiltration. Ed. de l'ORSTOM, Paris, 229 pp.

Chen, Y., Tarchitzky, J., Brouwer, J., Morin, J., Banin, A., 1980. Scanning electron microscope observations on soil crusts and their formation. Soil Sci. 130, 49-55.

Chiang, S., Radcliffe, D., Miller, W., 1993. Hydraulic properties of surface seals in Georgia soils. Soil Sci. Soc. Am. J. 57, 1418-1426.

Duley, F., 1939. Surface factors affecting the rate of intake of water by soils. Soil Sci. Soc. Am. Proc. 4, 60-64. 
Epstein, E., Grant, W.J., 1967. Soil losses and crust formation as related to some soil physical properties. Soil Sci. Soc. Am. Proc. 31, 547-550.

ESRI, 1992. Understanding GIS, the Arc/Info Method. Environmental Systems Research Institute, Redlands, CA, U.S.A.

Falayi, O., Bouma, J., 1975. Relationship between the hydraulic conductance of surface crusts and soil management in a typic Hapludalf. Soil Sci. Soc. Am. Proc. 39, 957-963.

Farres, P., 1978. The role of time and aggregate size in the crusting process. Earth Surf. Processes 3, 243-254.

Fox, D.M., Le Bissonnais, Y., Quétin, P., 1998. The implications of spatial variability in surface seal hydraulic resistance for infiltration in a mound and depression microtopography. Catena 32 (2), 101-114.

Freebairn, D., Gupta, S., Rawls, W., 1991. Influence of aggregate size and microrelief on development of surface soil crusts. Soil Sci. Soc. Am. J. 55, 188-195.

Hillel, D., Gardner, W., 1969. Steady infiltration into crust-topped profiles. Soil Sci. 108, 137-142.

Le Bissonnais, Y., Bruand, A., 1993. Crust micromorphology and runoff generation on silty soil material during different seasons. In: Poesen, J.W.A., Nearing, M.A. (Eds.), Soil surface sealing and crusting. Catena Supplement 24, 1-16.

Le Bissonnais, Y., Renaux, B., Delouche, H., 1995. Interactions between soil properties and moisture content in crust formation, runoff and interrill erosion from tilled loess soils. Catena 25, 33-46.

Luk, S., Dubbin, W., Mermut, A., 1990. Fabric analysis of surface crusts developed under simulated rainfall on loess soils, China. In: Bryan, R.B. (Ed.), Soil erosion, experiments and models. Catena Supplement 17, $29-40$.

McIntyre, D., 1958a. Permeability measurements of soil crusts formed by raindrop impact. Soil Sci. 85, $185-189$.

McIntyre, D., 1958b. Soil splash and the formation of surface crusts by raindrop impact. Soil Sci. 85, 261-266.

Norton, L., 1987. Micromorphological study of surface seals developed under simulated rainfall. Geoderma $40,127-140$.

Onofiok, O., Singer, M., 1984. Scanning electron microscope studies of surface crusts formed by simulated rainfall. Soil Sci. Soc. Am. J. 48, 1137-1143.

Philip, J., 1958. The theory of infiltration: 6. effect of water depth over soil. Soil Sci. 85, 278-286.

Sharma, P., Gantzer, C., Blake, G., 1981. Hydraulic gradients across simulated rain-formed soil surface seals. Soil Sci. Soc. Am. J. 45, 1031-1034.

Valentin, C., 1986. Effects of soil moisture and kinetic energy on the mechanical resistance of surface crusts. In: Callebaut, F., Gabriels, D., De Boodt, M. (Eds.), Assessment of Soil Surface Sealing and Crusting. Proc. of international symposium, Ghent, Belgium, pp. 367-369.

Valentin, C., 1991. Surface crusting in two alluvial soils of northern Niger. Geoderma 48, 201-222.

West, L.T., Chiang, S.C., Norton, L.D., 1992. The morphology of surface crusts. In: Sumner, M.E., Stewart, B.A. (Eds.), Soil Crusting, Chemical and Physical Processes. Advances in Soil Science. Lewis Publishers U.S.A., pp. 73-92. 